\title{
EFFECTS OF HUMAN ACTIVITIES ON THE DYNAMICS OF PLANT FORMATIONS IN THE COMMUNE OF TANGUIETA IN NORTHWEST OF BENIN
}

\author{
Rodrigue T. A. ABALO, Djafarou ABDOULAYE, Florence K. GBESSO and Brice A.H. TENTE \\ Biogeography and Environmental Expertise Laboratory \\ https://doi.org/10.35410/IJAEB.2020.5469
}

\begin{abstract}
The deterioration of the ecosystems constitutes a threat for the survival of the populations. The global objective of this research is to determine the human activity effects on the spatio temporal plant formation evolution in the northwest of Benin.

The technique of Schwartz (1995) permitted to interrogate 184 agricultural households in order to know the perception of the populations on the direct factors of pressures on the plant table setting. The software XLSTAT has been used for the Factorial analysis of the Correspondences in order to determine the values of importance that constitute the main reasons of deterioration of the plant table setting.

The pictures Landsat TMS of 1986, 2000 and 2017 have been used for the analysis diachronique of the plant table setting. To the exit of this methodology, he/it comes out again that with 0,89 value of importance, agriculture is respectively the first direct factor of destruction of the consistent plant table setting of the production of wood coal $(0,55)$, of the wood of œuvre $(0,36)$ and of raising $(0,18)$. The analysis of the dynamics of the units of soil occupation reveals a regression of 4205,97 hectare between 1986-2000 and 20260,82 hectares between 2000-2017. On the other hand, the mosaics of cultures and fallows, the plantations and the agglomerations as for them knew a progression of 3587,83 hectare between 1986-2000 and 6611,53 hectares between 2000-2017. Facing this situation of deterioration of the woody, him urge to afforest and to sensitize the different actors on the lasting natural resource management.
\end{abstract}

Keywords: Agricultural activities, effects, deterioration, natural resources and Tanguiéta.

\section{INTRODUCTION}

The world's forests, oceans and other water bodies are the main life-sustaining mechanisms on planet earth (FAO, 2013, p.200). They are essential for maintaining the biodiversity of natural ecosystems and for regulating the planet's climate system (H. Afouda, 2016, p.10). The sustainable management of the vast and diversified natural forest resource is proving to be a great challenge (IPCC, 2013, p.207). However, the rural and urban populations of Africa depend on ecosystem services for their basic needs, which means that the continent is faced with the increasingly acute and generalized problem of environmental degradation (P. D Kombienou, 2016, p. 39). 
In Benin, the plant formations which in 1976 covered $60 \%$ of the Beninese territory, experienced a significant decline. Indeed, in 2013, the National Center for the Management of Wildlife Reserves (CENAGREF, p.66) stated that in 1990 forest formations were evaluated at 4,923,000 ha, or $44 \%$ of the total area of the national territory. They went from 2007 to 2015 from 2.7 million hectares to 2 million hectares, from $19 \%$ to $14.07 \%$. Thus in less than 40 years, from 1976 to 2015, the loss of plant cover in Benin is estimated at $45.93 \%$. Studies carried out by the Beninese Environment Agency have shown that deforestation is taking on alarming proportions and is currently affecting forest resources which are under various pressures and the forest cover continues to decline year by year over the entire extent of national territory (ABE, 2010, p.77).

The Municipality of Tanguiéta is not spared this strong pressure on natural plant resources and especially that of forests because of anthropic activities and agro-pastoral activities in particular. This research aims to analyze the dynamics of plant formations and the evolution of agricultural areas in the Commune of Tanguiéta in North Benin.

\section{MATERIALS AND METHODS}

\subsection{Presentation of the study area}

The Commune of Tanguiéta is located in the northern part of the far west of Benin. It lies between the parallels $10^{\circ} 24^{\prime}$ 'and $11^{\circ} 28^{\prime}$ ' north latitude and between the meridians $1^{\circ} 02$ ' and $1{ }^{\circ} 56^{\prime}$ longitude and extends over an area of 5456 square kilometers $\left(\mathrm{km}^{2}\right)$. It enjoys a Sudanese-type climate and the rainy season covers the period from mid-April to mid-October, distributed according to a unimodal regime, with a maximum located in September (H. Tokobou, 2013, p.29. average annual rainfall ranges from $1000 \mathrm{~mm}$ to $1100 \mathrm{~mm}$ (ASECNA, 2018, p.38).

The vegetation is made up of natural formations (open forests, wooded, tree and shrub savannahs and saxicolous savannas) and plantations of Tectona grandis, Anacardium occidentale and Gmelina arborea (I. Ourou-Barrè, 2010, p.27). The soils are ferruginous, tropical, ferralitic and hydromorphic. The main stream that crosses the study area is the Pendjari River and is fed by temporary streams (H. Tobokou, 2013, p. 28). Figure 1 shows the geographic and administrative situations. 


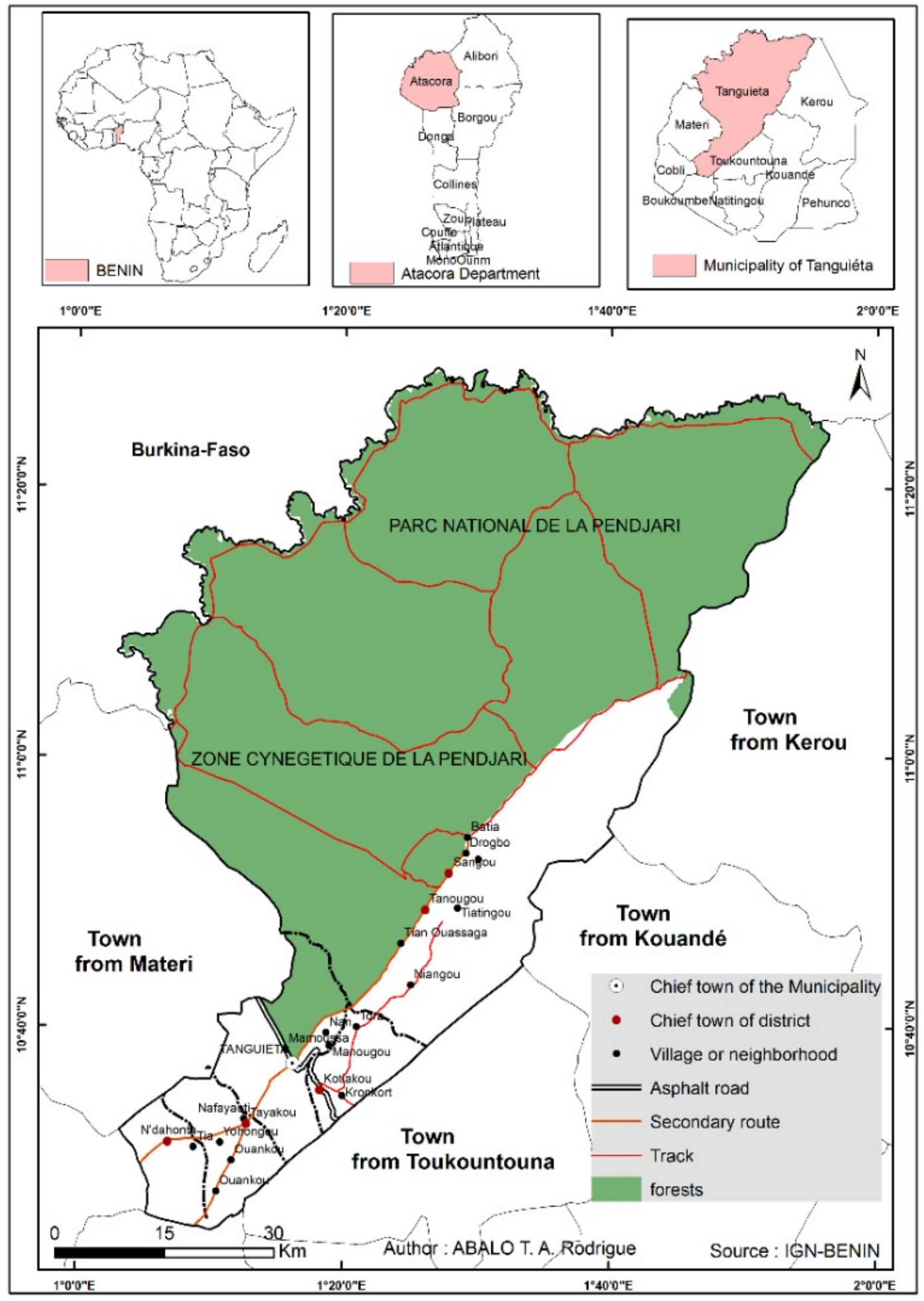

Figure 1: Geographic and administrative locations of the Municipality of Tanguiéta 
Vol. 5, No. 01;2020

ISSN: 2456-8643

The Commune of Tanguiéta is bordered to the north by Burkina Faso; to the south by the Communes of Toucountouna, Boukombé; to the east by the Municipalities of Kérou, Kouandé, Toucountouna and to the west by those of Mater and Cobly. This sector enjoys particular physical conditions, which favor agricultural activities, animal husbandry and logging.

\subsection{Research methods}

\subsubsection{Data used}

The Landsat TM OLI images of 1986, 2000 and 2017 were used for the land cover maps. Statistics on the evolution of agricultural areas from 1995 to 2017 are taken from the Ministry of Agriculture, Livestock and Fisheries (MAEP, 2018). The sample size is determined by the formula of D. Schwartz (1995, p.214) and 184 heads of agricultural households were chosen for the survey. Data from the National Institute for Economic Statistics from 2013 were used for this sampling. In addition to the heads of agricultural households, a reasoned choice made it possible to question forty-six (46) resource people to complete the number of households surveyed. In total, the sample size of the people surveyed is 230 people.

\subsubsection{Data collection tools, materials and techniques}

Questionnaire cards are sent to loggers and an interview guide was used to interview the authorities. Regarding the equipment, a digital camera to take pictures of the activities carried out by the population. As for the data collection techniques used, they relate to interviews with the municipal authorities and resource persons in order to better understand the questions linked to the degradation of the vegetation. Direct observations made it possible to see the various activities that are practiced in the environment and the situation of destruction of the plant cover.

\subsubsection{Method of processing and analyzing the results}

The importance of the importance of the choice of determinants made it possible to assess the importance of the direct determinants which participate in the destruction of plant formations. This parameter was used in ethnobotany to assess the extent of the use of certain plants by A. Byg and H. Balslev, (2001, p.951-970) in Madagascar. It varies from 0 to 1 and is determined by the following formula: IV $=$ nis $/ \mathrm{n}$. With nis the number of respondents who consider a factor as a determinant of degradation of plant formations and $\mathrm{n}$ the total number of respondents. For data processing, the Excel spreadsheet made it possible to produce the figures and the Arc GIS 10.1 software is used to produce the land use maps.

\subsubsection{Estimated population}

The estimate of the population at a date $(t+n)$ is the product between the rate of increase plus $n$, all at the power $n-t$ and the population $(t)$. It is expressed by the formula: $\mathrm{Pt}=\mathrm{Pn}(1+\mathrm{r}) \mathrm{n}-\mathrm{t}$

$-\mathrm{r}=$ rate of increase; $\mathrm{t}=$ reference year; $\mathrm{Pn}=$ reference population;

- $\mathrm{n}=$ estimated year; $\mathrm{Pt}=$ population to be estimated.

- The population growth rate (r) is determined by the following formula: 
$r=\frac{P 1-P 0}{P t} 100$ With : calculated by the formula: $T=\frac{\ln S 2-\ln S 1}{t \ln e} \times 100$ With:

- S1 and S2: Area of a landscape unit on the date $\mathrm{t} 1$ and $\mathrm{t} 2$ respectively;

- t2 - t1: Number of years of evolution;

- In: Natural logarithm; e: Base of natural logarithms $(e=2.71828)$. At the end of this methodology, the following results were obtained.

\section{RESULTS}

\subsection{Demographic pressure and socio-economic activities}

This part concerns demographic pressure, agro-pastoral activities and the exploitation of forest resources which are sources of the degradation of plant formations.

\subsubsection{Population pressure and vegetation degradation}

The conversion of wooded land to a cultivated area responds to the pressure of increasing food needs resulting from population growth (Akpinfa, 2017). Figure 2 shows the evolution of the population and its trend from 1979-2050.

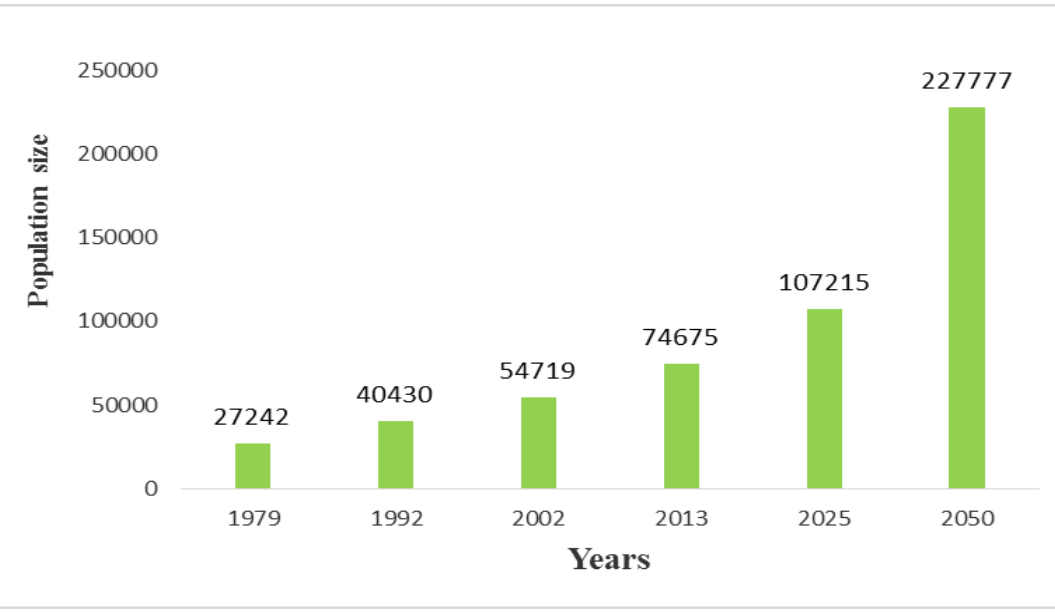

Figure 2: Evolution of the population of the Municipality of Tanguiéta from 1979 to 2050 Source: INSAE, 2013

Demographic pressure in the study environment is manifested by strong pressure on plant resources, through the exploitation of timber, the extension of agricultural land leading to the destruction of plant species.

\subsubsection{Direct determinants of vegetation degradation}

Several activities justify the pressures on wood resources. The importance value of the direct determinants of wood harvesting is presented in Figure 3. 


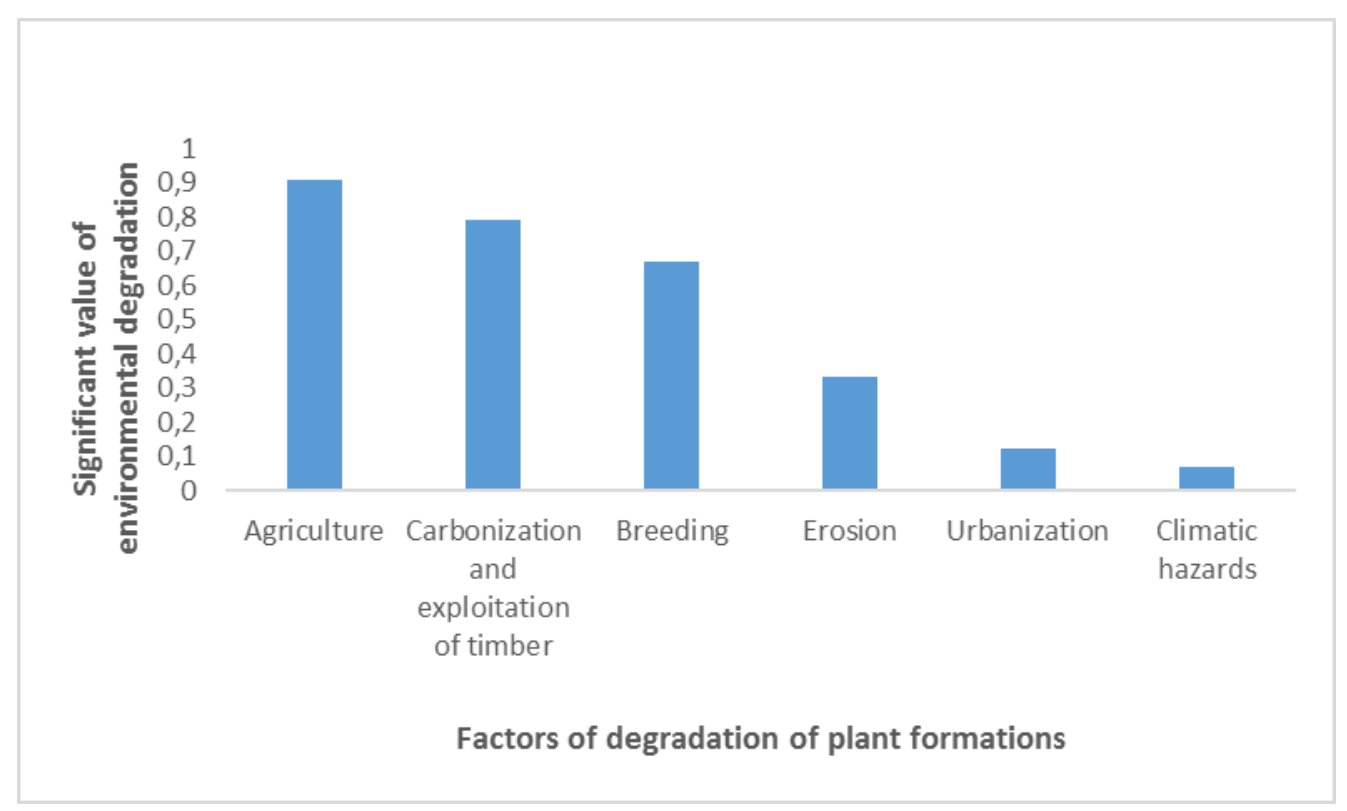

Figure 3: Significance value of woody harvesting factors

Source: Field survey, December 2018

Analysis of figure 3 reveals that the direct drivers of wood harvesting are anthropogenic. These factors include agriculture (0.89), charring (0.55), lumbering (0.36) and livestock (0.18). Agriculture is the first most destructive factor in wood resources through crop clearing. This is followed by the production of charcoal. Breeding with low importance value and the pruning of plants are seen as determinants of the degradation of woody plants.

\subsubsection{Evolution of the sown agricultural areas}

Agriculture constitutes the first activity and occupies more than $70.5 \%$ of the populations of the Municipality of Tanguiéta. Figure 4 shows the evolution of the area sown with the main food crops. 
Vol. 5, No. 01;2020

ISSN: $2456-8643$

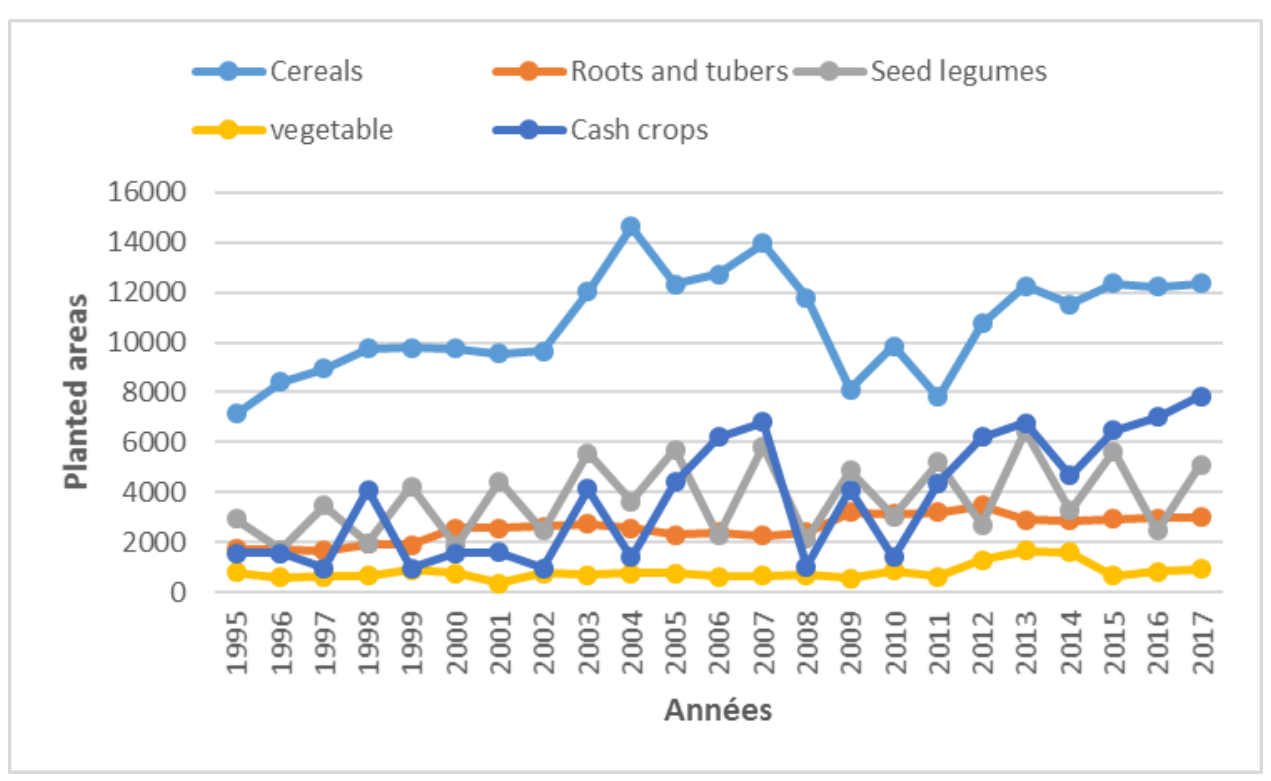

Figure 4: Evolution of plantings by category of speculation in the study area

Source: MAEP / DPP, 2018

The analysis in figure 4 shows an overall upward trend in the area sown for the different categories of speculation. Thus, the area sown for cereals increased from 7,133 ha during the 1995-1996 crop year to 12,346 ha in 2016-2017, an increase of 5,213 ha. For roots and tubers, they increased during the same seasons from 1,731 ha to 3,020 ha, or 1,289 ha. Legumes, which occupied 2,931 ha in 1995, increased to 5,107 ha in 2017, an increase of 2,176 ha. As for vegetable crops, they increased from 803 ha to 941 ha in 2017, an increase of 138 ha. Finally, cash crops during the same period increased from 1,567 ha to 7,852 ha, an evolution of 6,285 ha. The frantic conquest of new lands is done to the detriment of forests is aggravated by the farming techniques practiced (photo 1).

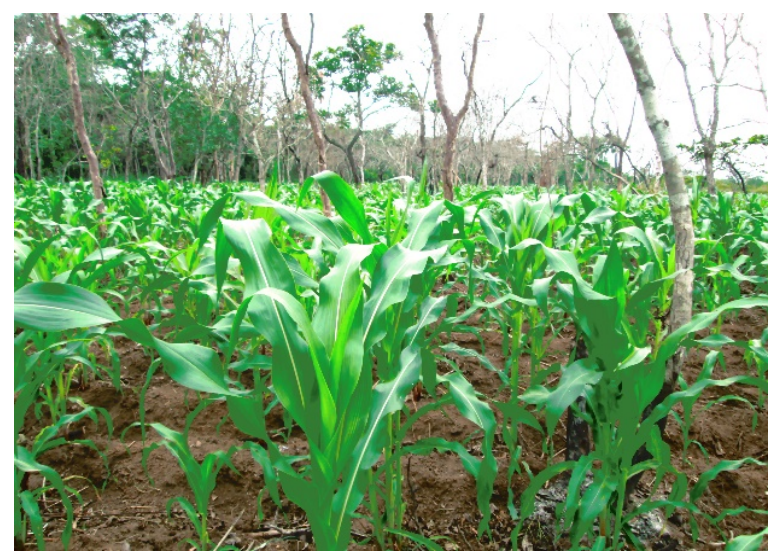

Photo 1: Corn field in Bounta

Shooting: Abalo, July 2018 
Vol. 5, No. 01; 2020

ISSN: $2456-8643$

Through photo 1, we can see a corn field in Bouata where all the trees are burned on feet to allow a rapid growth of the crop.

\subsubsection{Crop technique factor in the degradation of plant formations}

It is based on itinerant slash-and-burn cultivation. Field surveys have shown that new fields are being opened up to the detriment of forest areas by farmers, even in the hunting area. Photo 1.1 shows a burnt field and photo 1.2 shows a yam field in Cotiakou.

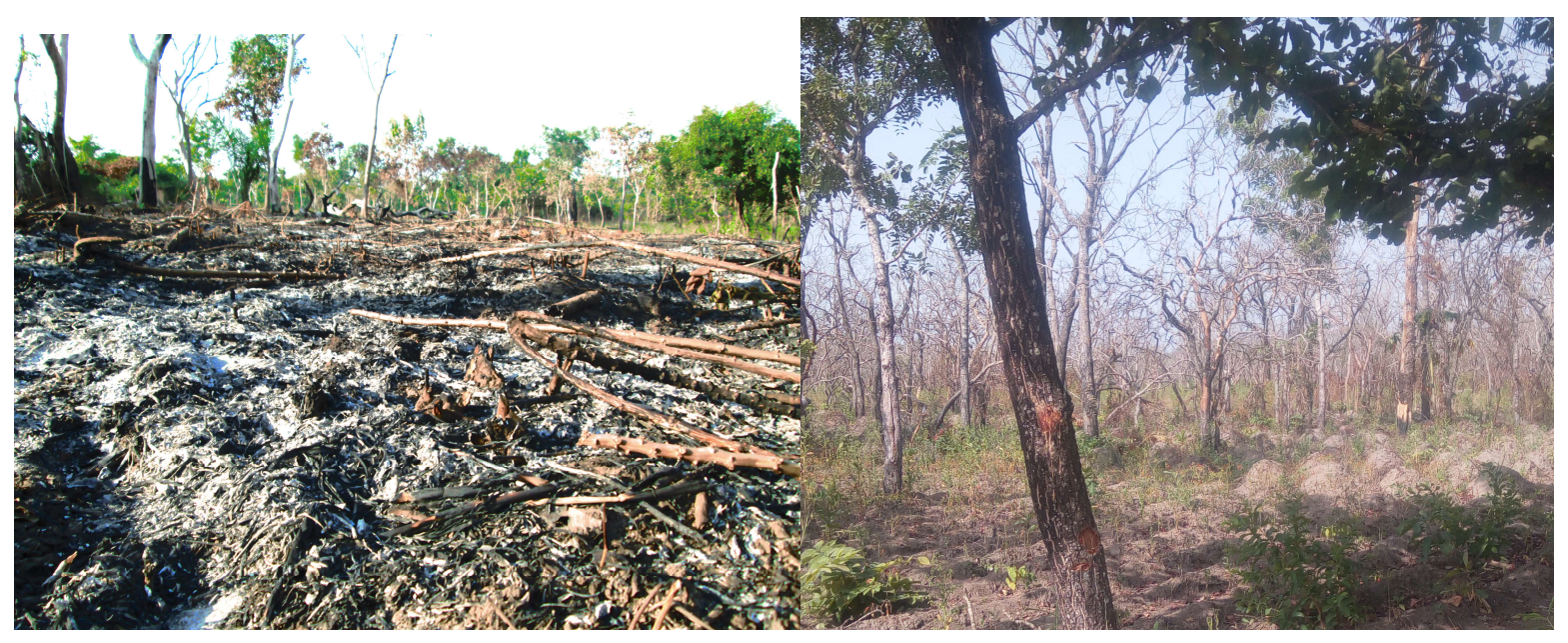

Plate 1: Shifting cultivation on slash and burn in Sangou and yam fields in Cotiakou

Shooting: Abalo, July 2018

Photos 1.1 and 1.2 respectively show the slash-and-burn cultivation technique and a yam field that extends as far as the eye can see in Cotiakou. Dozens of hectares of fields are observed where the only trees that exist are species that pose no obstacle to the development of crops. The cultivation of yam (Dioscorea spp), a heliophilous and creeping plant, requires a lot of space and light, leading farmers to kill trees for their benefit. The populations are engaged in pastoral activities.

\subsubsection{Breeding}

The Pendjari National Park constitutes for pastoralists the place of pasture in the hunting area before the deprivation of the park by the Beninese government to AFRICAN PARK. The richness of this reserve in fodder and water points in dry periods is an attraction for local pastoralists and transboundary transhumants (photo 3). 


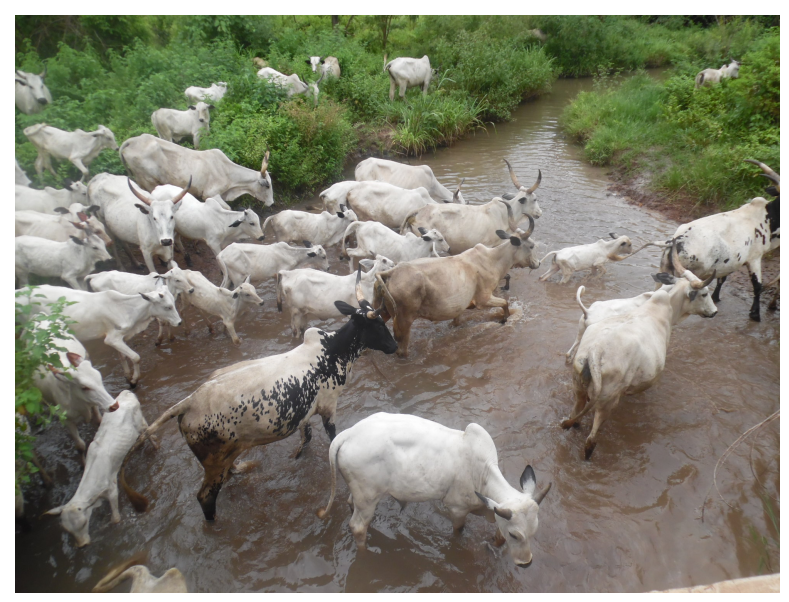

Photo 2: Herds of cattle at Corroncure Shooting: Abalo, November 2018

The observation in photo 2 shows a strong presence of livestock mainly due to the presence of pastoral resources. The richness of these reserves in fodder and water points during wet periods is an asset. Transhumance is however exerting increasing pressure on natural pastures. Heavy loads cause compaction of the soil and infiltration becomes difficult, favoring a linear runoff of water that is observed in the rainy season. In addition, the uncontrolled pruning of fodder trees such as Khaya senegalensis, Afzelia africana, Pterocarpus erinaceus will lead to their disappearance in the long term. The massive displacement of livestock in search of pastures and water points causes environmental degradation. Animal pressure with the transhumance of animals also constitutes a source of conflict between breeders and farmers. Figure 5 shows the evolution of the livestock from 2010-2017 
Vol. 5, No. 01;2020

ISSN: 2456-8643

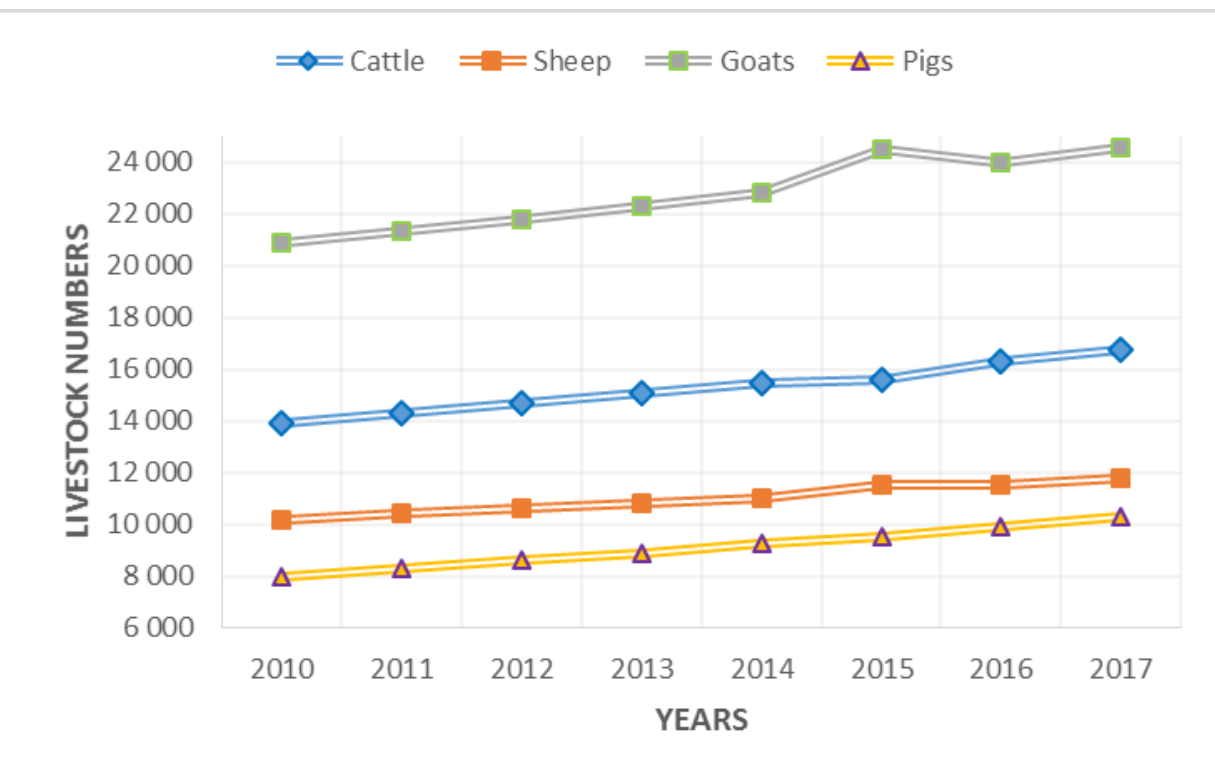

Figure 5: Evolution of livestock in the Municipality of Tanguiéta from 2010-2017

Source: Directorate of Livestock and Fisheries, September 2018

Figure 5 shows the evolution of the different herds. The number of cattle heads to feed increased from 13,900 heads in 2010 to 16,722 heads in 2017 , i.e. a growth of 2,822 heads in seven (07) years, except the quantity of fodder remains practically stable. The trampling and heavy accumulation of soil make plowing very difficult. Also, the repeated passage of large numbers of herds creates vast artificial corridors with the corollary of the deterioration of the land and plant cover due to the regular trampling of the ground and intensive browsing. From this point of view, transhumance is a practice that accelerates the process of degradation of plant formations.

\subsubsection{Logging}

The main species exploited are: Khaya senegalensis, Afzelia africana and Pterocarpus erinaceus. This pressure justifies the regression of natural vegetation in favor of anthropogenic activities. Photo 2.1 photo 2.2 shows a truck full of planks in Batia. 


\section{International Journal of Agriculture, Environment and Bioresearch}

Vol. 5, No. 01; 2020

ISSN: $2456-8643$

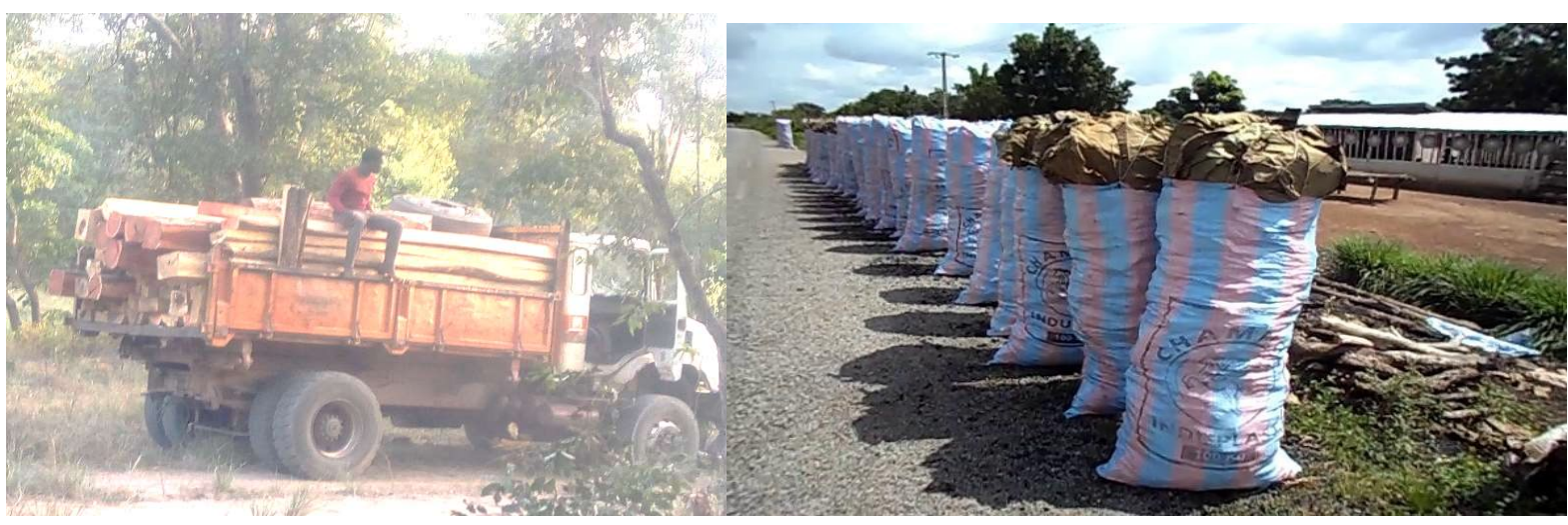

Plate 2: Truck loaded with planks and exhibition of wood from sacks of coal in Coutiakou Shooting: Abalo, November 2018

The observation in photo 2.1 shows a truck transporting logs to Batia. Field surveys of the Tanguiéta forestry authorities have revealed that around one hundred thousand three twenty-two $(100,322)$ feet of trees are cut each year. As for the carbonization illustrated in photo 2.2, it is intended for sale to buyers in urban centers and for local consumption.

\subsection{Dynamics of spatio-temporal changes in land use}

Spatio-temporal changes in land use units in the study environment are assessed through the land cover maps of 1986, 2000 and 2017.

\subsubsection{State of land use in 1986}

The status of the 1986 land occupation units is shown in Figure 6. 
Vol. 5, No. 01; 2020

ISSN: $2456-8643$

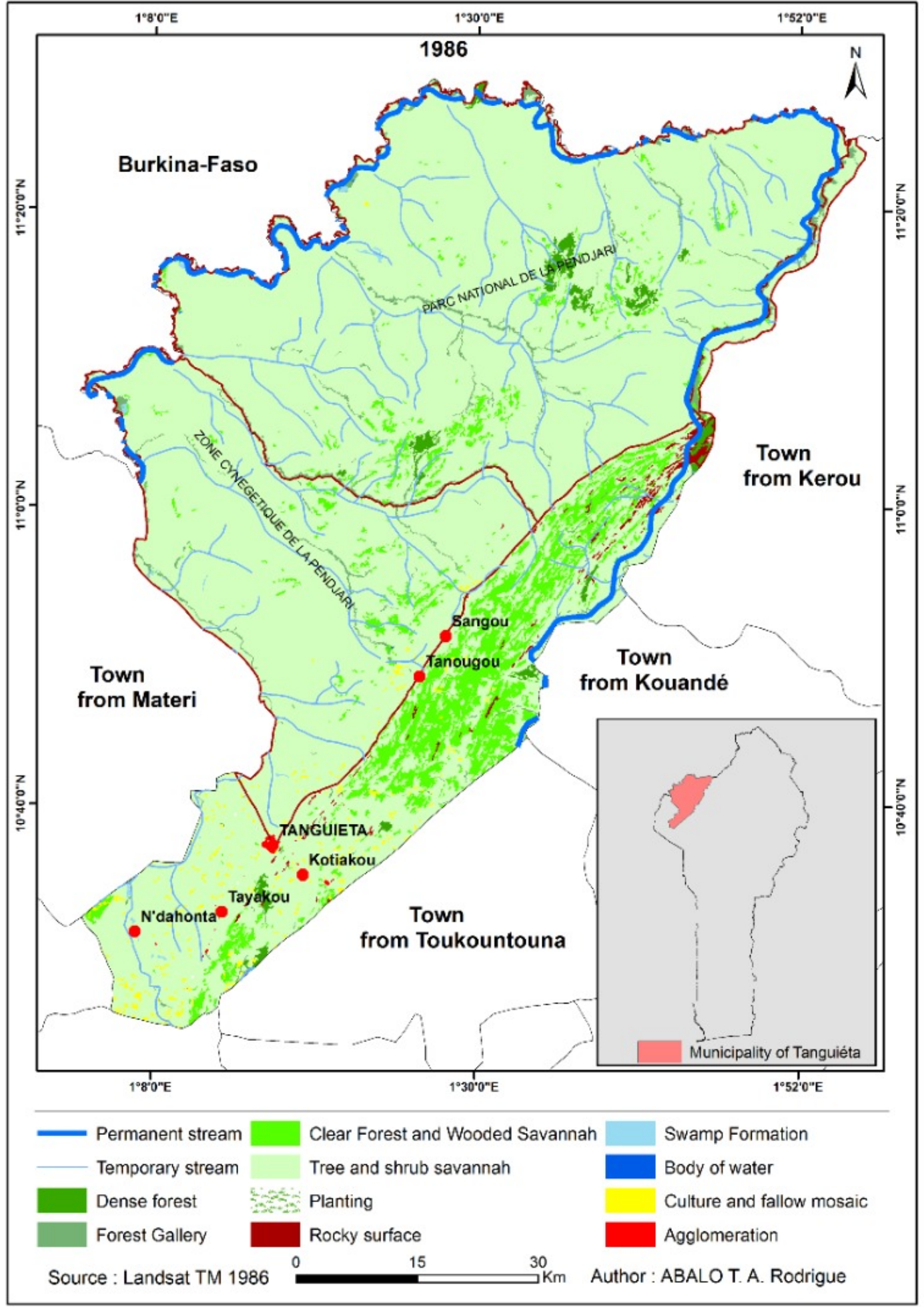

Figure 6: State of 1986 land use units in the study area 
It is evident from the observations in Figure 6 that the open forests and wooded savannahs occupy the protected areas, the islets of dense dry forest are remarkable in the heart of Pendjari Park and the forest galleries are observed along the rivers. The agglomerations are scattered along the roads, especially on the Natitingou-Ouagadougou road axis and around water points. Figure 7 is used to use in 2000.

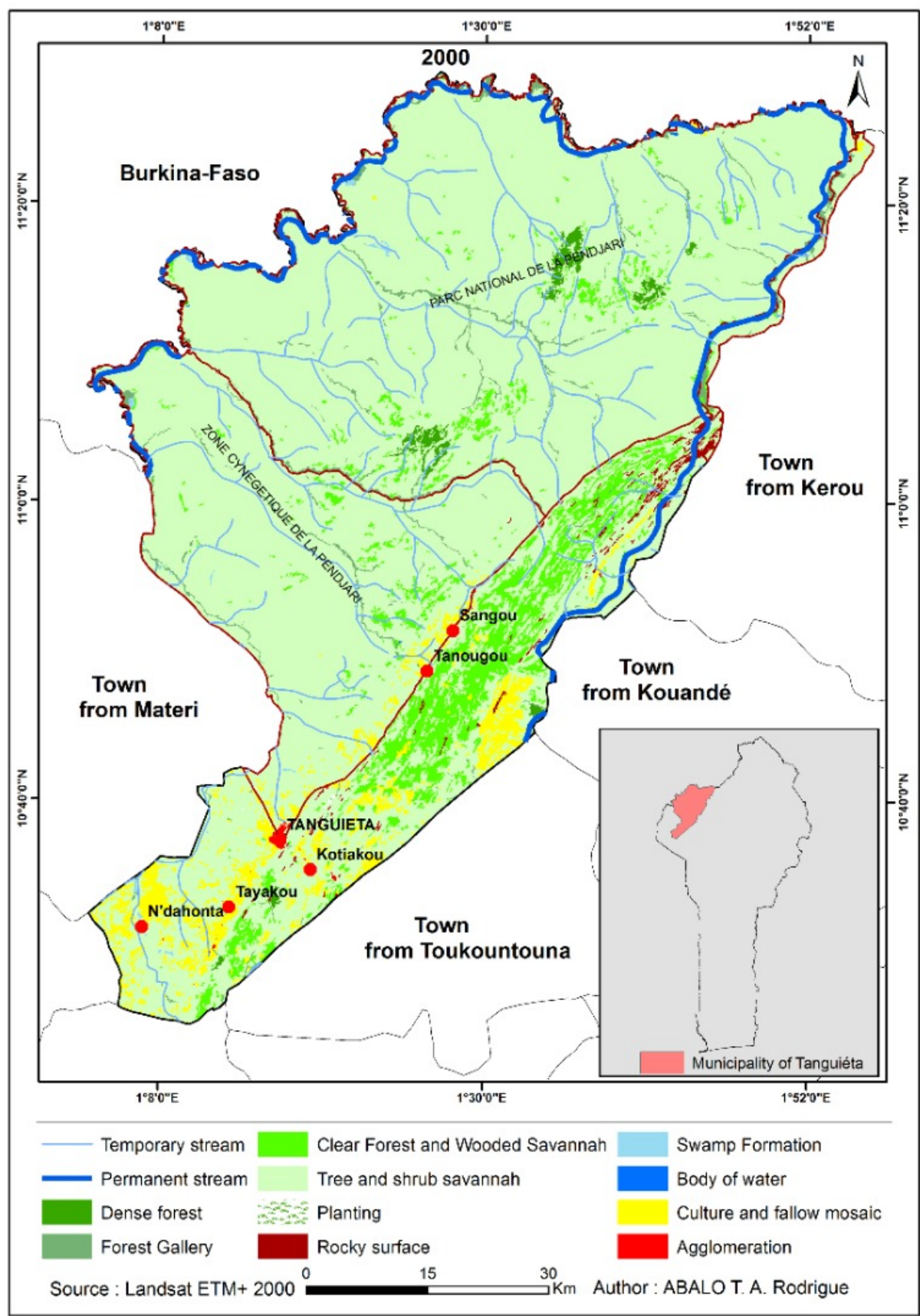

Figure 7: State of the 2000 land occupation units of the Municipality of Tanguiéta 
Vol. 5, No. 01;2020

ISSN: $2456-8643$

The observation of Figure 7 shows ten (10) land cover units in 2000. These units present are: agglomerations, gallery forests, swamp formations, open forests and wooded savannas, tree and shrub savannas, bodies of water, mosaics of fields and fallows, plantations and rocky surfaces.

\subsubsection{Dynamics of land use between 1986 and 2000}

The statistical analysis of the spatio-temporal changes in land use between 1986-2000 is presented in Table I.

Table 1: Average annual rate of spatial expansion and conversion rate of land use units from 1986 to 2000

\begin{tabular}{|c|c|c|c|c|}
\hline Unités d'occupation du sol & Sup 1986 (ha) & $\begin{array}{r}\text { Sup } 2000 \\
\text { (ha) }\end{array}$ & $\begin{array}{r}\text { TAA } \\
(1986- \\
2000)\end{array}$ & Bilan \\
\hline Agglomeration & 468,37 & 601,93 & 2,04 & progression \\
\hline Clear Forest and Wooded & & & 0,05 & Regression \\
\hline Savannah & 42870,02 & 43152,15 & & \\
\hline Dense forest & 6234,63 & 4531,45 & $-1,95$ & Regression \\
\hline Swamp Formation & 833,50 & 833,50 & 0 & Stability \\
\hline Forest Gallery & 15014,06 & 14705 & $-0,15$ & Regression \\
\hline Culture and fallow mosaic & 14927,90 & 18382,17 & 1,65 & progression \\
\hline Body of water & 127,36 & 127,36 & 0 & Stability \\
\hline Planting & 133,27 & 133,27 & 0 & Stability \\
\hline Tree and shrub savannah & 472280,54 & 469804,68 & $-0,04$ & Regression \\
\hline Rocky surface & 2665,09 & 2665,09 & & Stability \\
\hline Totaux & 555836,83 & 555245,67 & & \\
\hline
\end{tabular}

Source: Image Landsat TM, 1986 and Landsat, 2000

ha $=$ hectare and TAA $=$ Annual Growth Rate

Reading Table I shows that the physiognomy of land use in 1986 and 2000. In 1986 natural plant formations occupied an area of 536,399.25 ha. In 2000, this area increased to 532,193.28 ha, with a regression of $4,205.97$ ha or $40.62 \%$ of the total area in 2000 . The mosaics of crops and fallows, plantations and agglomerations are increased from 15,529.54 ha in 1986 to $19,117.83$ ha, i.e. an increase of 3,587.83 ha in their areas in 2000 to the detriment of gallery forests, tree and shrub savannas. As for the water bodies and the rock surfaces, they remained almost stable 
over time without undergoing any particular modification. According to field surveys, these spatial units have decreased due to agriculture and logging. The tree savannas are constantly disturbed by humans. They are burned, grazed, cleared for wood, new land for agriculture. Figure 8 shows the 2017 land cover map.

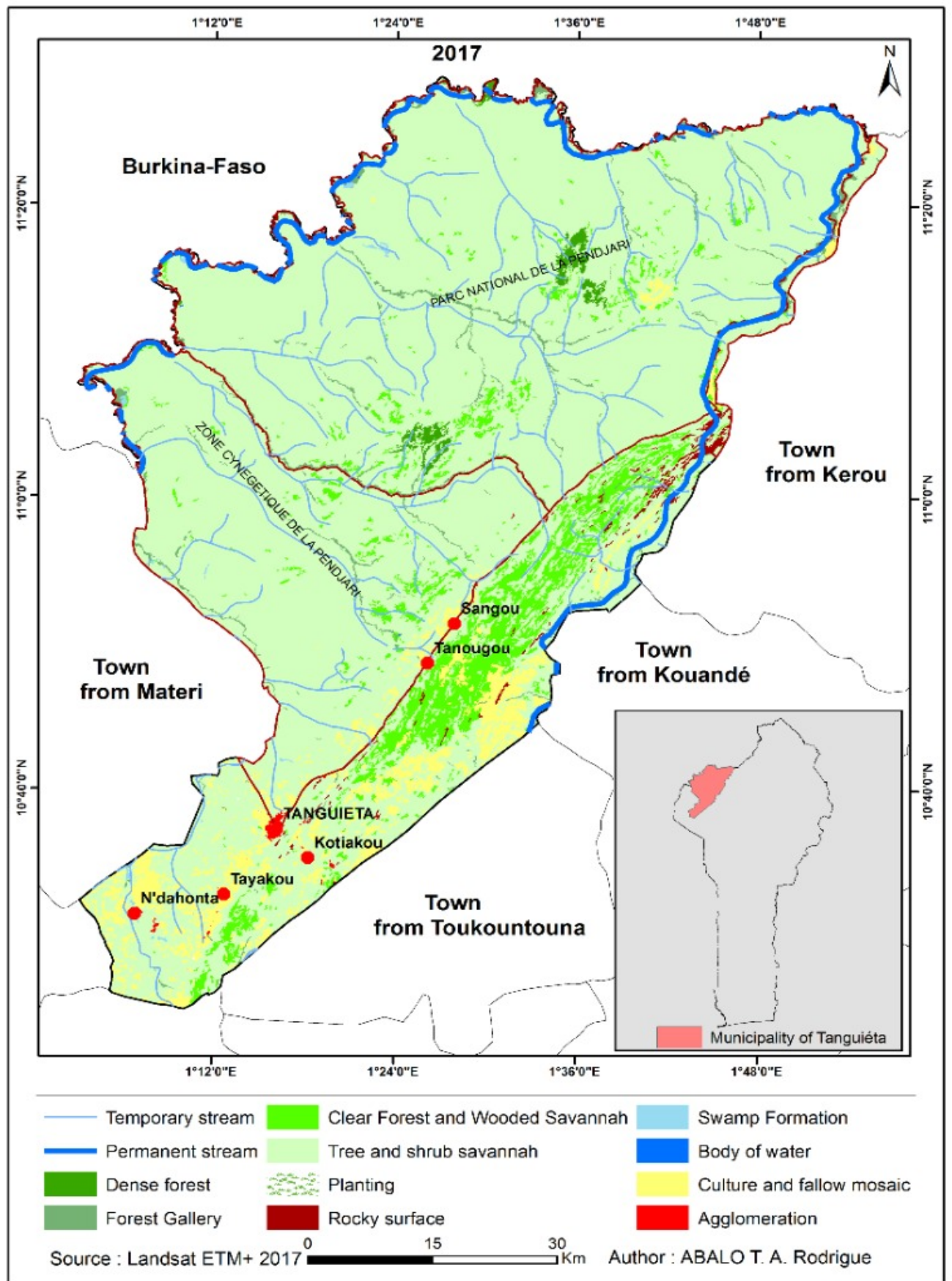

Figure 8: State of 2017 land use units in the study area 
Vol. 5, No. 01;2020

ISSN: $2456-8643$

Figure 8 shows the same land cover units for 2017. The natural formations that predominated in 2000 have deteriorated in favor of anthropogenic formations.

\subsubsection{Summary of the conversion of the plant formations of 1986, 2000 and 2017}

Table 2 describes the conversion balance for plant formations and land use units between 2000 and 2017.

Table 2: Average annual rate of spatial expansion and conversion rate of land use units from 2000 to 2017

\begin{tabular}{|lrrrl|}
\hline Unité d'occupation du sol & $\begin{array}{r}\text { Sup 2000 } \\
\text { (ha) }\end{array}$ & Sup 2017 (ha & TAA (2000-2017) & Bilan \\
\hline Agglomeration & 601,93 & 798,69 & 2,33 & progression \\
Clear Forest and Wooded & & & $-0,49$ & Regression \\
Savannah & 43152,15 & 40198,16 & $-0,72$ & Regression \\
Dense forest & 4531,45 & 4071,79 & 0 & Stability \\
Swamp Formation & 833,5 & 833,5 & $-0,41$ & Regression \\
Forest Gallery & 14705,00 & 14482,54 & 3,34 & progression \\
Culture and fallow mosaic & 18382,17 & 24612,40 & 0 & Stability \\
Body of water & 127,36 & 127,36 & 5,21 & progression \\
Planting & 133,27 & 318,39 & $-0,03$ & Regression \\
Tree and shrub savannah & 469804,68 & 467662,51 & & Stability \\
Rocky surface & 2665,09 & 2540,34 & $\mathbf{5 5 5 2 4 5 , 6 7}$ & \\
\hline Totaux & $\mathbf{5 5 5 2 4 5 , 6 7}$ & & & \\
\hline
\end{tabular}

Source: Landsat TM Image, 2000 and Landsat, 2017

ha $=$ hectare and TAA $=$ Annual Growth Rate

The analysis of Table II clearly identifies the different conversions carried out inside and in the land use classes between 2000 and 2017.

In fact, the forest galleries which occupied 14,705 ha in 2000 increased to 14,265.54 ha in 2017 . 439.46 ha of these formations are converted into mosaics of fields and fallows. Likewise, dense forests, open forests and wooded savannas and tree and shrub savannas which were estimated at 4531.45 ha; $43,152.15$ ha and 469,804.68 ha respectively increased from 4,071.79 ha; 40,198.16 
Vol. 5, No. 01; 2020

ISSN: $2456-8643$

ha and 467,662.51 ha, i.e. a decrease in their coverage of 459.66 ha, 2,954 ha and 423,024 ha. On the other hand, the rock surfaces (2,665.09 ha) and the water bodies (127.36 ha) remained unchanged.

The mosaics of fields and fallows, agglomerations and plantations have progressed. In 2000, the mosaics of fields and fallows estimated at 18,382.17 ha increased to 24,612.40 ha, an increase of 6,230.23 ha in 17 years. The agglomerations increased from 601.93 ha to 798.69 ha, an increase of 196 ha. With regard to plantations, the areas in 2000 increased from 133.27 ha to 318.27 ha, with an increase of 185 ha or $54.72 \%$.

Overall, all of the land occupation units have undergone a change in their areas according to whether they were natural formations or anthropogenic formations.

Natural plant formations in 1986 fell from $536,399.25$ ha to $532,193.28$ ha in 2000 , a decrease of 4,205.97 ha and from 532,193.28 ha to 511,932.57 ha in 2017, a drop of 20,260.82 ha in 2017.

On the other hand, anthropogenic formations (mosaics of crops and fallows, plantations and agglomerations) increased from $15,529.54$ ha in 1986 to $19,117.83$ ha of their areas in 2000, an increase of 3,587.83 ha. From 19,117.83 ha obtained in 2000, these formations increased to 25,729 ha in 2017, an increase of 6,611.53 ha. As for the water bodies and the rock surfaces, they remained almost stable over time without undergoing any particular modification. Indeed, the destruction of the plant formations observed is also linked to the impoverishment of the soils, which are degraded under the effects of water erosion and by irrational occupation and exploitation. This deterioration leads to a loss of fertility, a decrease in crop production and in yields for agriculture. This results in a significant modification of the natural plant cover (land clearing, deforestation, water erosion, reduction of fallows), a decrease in food security and a continuous migration to new soils.

\section{DISCUSSION}

The land cover maps produced have highlighted the general trend in the dynamics of land use. This general trend reveals an increase in the area of anthropogenic formations (fields and fallows, settlements, plantations) to the detriment of natural plant formations (forests, savannas). P. D. Kombienou (2016, p.158) had already reached the same conclusion in north-west Benin. More worryingly, this trend of degradation of plant cover does not even spare the protected areas of the watershed as D. Gounou N'gobi $(2012$, p. 25) was able to show by studying the impacts of climate change and activities anthropogenic on the classified forest of Sôta and its riparian zone. These results confirm those obtained in the Ouémé watersheds at the Bétérou outlet studied respectively by A. Akognongbé (2014, p. 153) and D. Abdoulaye (2015, p.122 who have shown that natural plant formations have experienced a decline in favor of anthropized formations. These results are consistent with those of S. Soulama et al., (2015, p 101) in south-eastern Burkina Faso. All these authors have come to the conclusion that natural plant formations decrease in favor of crops, bare soil, agglomerations and incidentally plantations. Once again, human pressure is the cause. 
Vol. 5, No. 01;2020

ISSN: $2456-8643$

These results are consistent with research carried out by TT Adjakpa, (2012, p. 10 and J. Odjoubéré (2014, p. 129) in the classified forest of Trois Rivières and Monts Kouffé, showing that the production of charcoal and logging are the main causes of the loss of woody plants and have repercussions such as the degradation of the plant cover and the bare soil therefore its depletion.

Along the same lines, Tente et al. $(2011, \mathrm{p} 8)$ have shown that agricultural activities are the major causes of vegetation degradation. Thus, the area of plant formations (savannahs and forests) is decreasing in favor of that of anthropogenic activities, notably fields and fallows and agglomerations. Indeed, the forestry potential is considerably reduced due to the accelerated exploitation of wood. These results are consistent with the analysis of woody resource maps of 1990 and 2014 conducted by TAR Abalo (2016, p.66 in the Commune of Dassa-Zoumé which revealed that plant formations have experienced a decline of $(40,429 \mathrm{ha})$ with the corollary the destruction of vegetation. These results are also confirmed by the work of Agbanou et al., (2018) by indicating that population growth and certain modes of exploitation are considered to be responsible for the degradation of ecosystems and land with the consequence of the disturbance of the ecological balances in the South-West of Niger.

Similarly, the uncontrolled pruning of certain plant species leads to the disappearance of these species in the long term (Djohy et al., 2016). This decline in natural plant formations is accompanied by the loss of biodiversity and land degradation.

The modification of climatic parameters in recent years, in particular the decrease in precipitation and the rise in temperatures induces a decrease in the availability of water resources and therefore influences agricultural production and plant formations (Afouda, 2016). The results of the work of many authors have shown that the situation of degradation of the natural plant formations of the Commune of Tanguiéta is not a peculiarity in Benin.

\section{CONCLUSION}

The local economy of the Commune of Tanguiéta is dominated by the primary sector, notably the agricultural sector. However, the extension of agricultural production based on shifting slashand-burn agriculture leads to an increase in the area sown with crops, leading to the destruction of plant formations. Also, the decline in agricultural yields poses a major risk to the food security of populations.

Livestock transhumant through pastures and pruning of fodder trees cause soil erosion and compaction by trampling. As for the excessive exploitation of woody plants, it leads to the scarcity of plant species such as Prosopis africana and Pterocarpus erinaceus. In addition, the mapping of the dynamics of plant formations and other land use units made it possible to analyze the states of the plant cover in 1986, 2000 and 2017 and to identify trends. In summary, the plant formations underwent a modification during this period. In general, natural formations decreased by $20,260.82$ ha while anthropized formations increased by $6,611.53$ ha.

In view of all of the above, it is clear that plant resources have been subject to deplorable losses and changes to the balance of the environment. The rare plant formations which are not yet 
Vol. 5, No. 01; 2020

ISSN: $2456-8643$

destroyed result from the endogenous management of plant resources which is a continuity of the management practiced by the ancient population through the conservation and protection of natural resources. To achieve this, a good vegetation management policy must go through comanagement with the effective participation of local populations.

\section{REFERENCES}

Abalo TV. Amoni. Rodrigue. (2016): Socio-economic and environmental effects of the exploitation of wood resources in a context of sustainable development in the Municipality of Dassa-Zoumé. DEA / EDP / UAC thesis, 99 p.

Beninese Environment Agency (2010): General guide for carrying out an environmental impact study. MEHU, Cotonou, Benin, 77 p.

Abdoulaye Djafarou. (2015): Dynamics of land use and its impact on flow in the Ouémé basin at the Outlet of Bétérou (North Benin). Doctoral thesis of the University of Abomey-Calavi. $253 \mathrm{p}$

Adjakpa Tchékpo. Theodore. (2012): Climate change, human activities and the dynamics of natural ecosystems in the classified forest of Trois Rivières in Benin. Master thesis / CIFREDEDP / UAC, 168 p.

Afouda Hervé. (2016): Climatic and dynamic variability of vegetation in the confluence of the Ouémé-Okpara (Benin). DEA / EDP / UAC thesis, 91 p.

6-Akognongbè Ansène. J. S. (2014): Influence of climate variability and anthropogenic activities on surface water in the Ouèmè-Bétérou basin in Benin. Doctoral thesis in Environmental Management, EDP / UAC, 255 p.

Agbanou T, Paegelow M, Toko II, Tenté B. (2018): Modeling of land use changes in the Sudanian region in north-west Benin, online, consulted on 01/10/2019, http: // eujournal . Org / index. php / esj / article / view / 10788.

Akpinfa Dossou. Edouard (2017): Degradation of agricultural land in the Communes of DassaZoumé and Glazoué in Benin: determinants and socio-economic implications. Single doctoral thesis, UAC, $365 \mathrm{p}$.

ASECNA (2018): Data from the Cotonou meteorological station, Climatological section, Cotonou, $38 \mathrm{p}$.

Atta Sanoussi, Achard François and Ould Mohamedou O. M. Sidi, (2010): "Recent evolution of the population, the occupation of the grounds and the floristic diversity on an agricultural soil of the South-West of Niger". Science \$ nature, 7 (2): 119-129.

Bernier Bernard. (1992): Introduction to macroeconomics. Dunod, Paris, 217 p.

Anja Byg A. \& Balslev Henrik. (2001): Diversity and use of palms in Zahamena, eastern Madagascar. Biodiversity and Conservation 10: 951-970. 
Vol. 5, No. 01;2020

ISSN: 2456-8643

National Center for Wildlife Reserve Management (2013): Analysis of the implementation of the current categorization of Protected Areas in Benin and Proposal for a new categorization of Protected Areas according to the new IUCN guidelines. CENAGREF / POPE, Cotonou. Progress report: Support mission. $66 \mathrm{p}$.

Djohy Gildas. Louis. Totin Henri. Sourou. Vodounon Nickson. Eesther. Kinzo. (2016): Dynamics of land use and evolution of agricultural land in the Municipality of Sinendé in North Benin. Notebooks of the CBRST, Beninese Center for Scientific and Technical Research 2016, pp.101-121.

FAO (2013): State of the world's forests. Food and agriculture Organization Rome, 200 p.

INSAE (2013): Fourth General Census of Population and Housing, February, 2013, Population dynamics, Cotonou, $35 \mathrm{p}$.

Kombienou P. D. (2016): Influence of agricultural production systems on land use, soil fertility and agro-biodiversity in mountainous areas in the Atacora department. Unique doctoral thesis in geography, FLASH, UAC, 281 p.

Ministry of Agriculture, Livestock and Fisheries (2018): DPP (Department of Programming and Prospective Compendiums of agricultural statistics for several Cotonou campaigns, $14 \mathrm{p}$.

Odjoubéré Jules. (2014): Pressures on woody plant species in the protection series of the Monts Kouffé classified forest in Benin. Unique doctoral thesis in geography, FLASH, UAC, 172 p.

Ouorou-Barrè Imorou. (2010): Climate variability and agricultural production in the Communes of Tanguieta and Material. DEA / EDP / UAC thesis, $109 \mathrm{p}$.

Schwartz Daniel. (1995): Statistical methods for use by physicians and biologists. 4th edition (Medical Editions Flammarion), Paris, 314 p.

Soungalo Soulama, Abel Kadeba, Blandine MI Nacoulma, Salifou Traoré, Yvonne Bachmann, Adjima Thiombiano (2015): Impact of anthropogenic activities on the vegetation dynamics of the Pama partial wildlife reserve and its peripheries (south-eastern Burkina Faso) in a context of climatic variability. Journal of Applied Biosciences 87: 8047- 8064 ISSN 1997-5902.

Tempted Brice. Baglo Marcel. Ayité. Dossoumou Jean. Cossi. Yédomonhan Hounnankpon. (2011): Impacts of human activities on forest resources in the village lands of the communes of Glazoué and Dassa-Zoumè in central Benin. International Journal of Biological and Chemical Sciences, 5 (5), 2022-2030.

Tokobou Hélène. (2013): Coal and wood energy production activities in the Municipality of Tanguiéta. Master thesis in geography, DGAT / FLASH / UAC, 78 p. 